\title{
Temperature-dependent Peptidergic Feedback: Potential Role in Seasonal Egg Laying in Aplysia
}

\author{
Renee Sanger Redman and Robert W. Berry \\ Department of Cell, Molecular, and Structural Biology, Northwestern University Medical School, Chicago, Illinois 60611
}

$\alpha$-Bag cell peptide ( $\alpha$-BCP), one of the secretory products of the neuroendocrine bag cells in Aplysia, has been reported by various investigators to have either excitatory or inhibitory feedback effects. Though conflicting, these results may be explained by the difference in temperature at which the experiments were performed. Because egg laying in this animal is temperature dependent, the alteration in function of this peptide by temperature may offer a possible molecular basis for the seasonal regulation of egg laying. This hypothesis was investigated by assessing the feedback actions of $\alpha-\mathrm{BCP}$ at various temperatures. At $15^{\circ} \mathrm{C}, \alpha-\mathrm{BCP}$ hyperpolarized bag cells, shortened the duration of synaptically evoked bag cell discharges, and reduced the number of action potentials per discharge. However, at $20^{\circ} \mathrm{C}$, the peptide depolarized bag cells, lengthened discharges, and increased the number of action potentials per discharge. A temperature-dependent influence on bag cell cAMP levels may underlie these effects, because $\alpha$-BCP reduced basal CAMP levels in intact bag cells at temperatures of $15^{\circ} \mathrm{C}$ and below, while at $17-22^{\circ} \mathrm{C}$ it increased these levels. However, the inhibitory effects of $\alpha$-BCP on stimulated adenylate cyclase activity in bag cell homogenates were not temperature dependent. Moreover, a low-Ca ${ }^{2+} / h_{i g h}-\mathrm{Mg}^{2+}$ solution abolished $\alpha$-BCP's ability to increase bag cell cAMP levels at $20^{\circ} \mathrm{C}$. This suggests that the peptide may evoke the secretion of an excitatory modulator at the higher temperature. These results imply that $\alpha-B C P$ is autoinhibitory at typical winter temperatures, but becomes autoexcitatory as ocean temperature rises in the summer. Thus, the peptide may function in coordination with other factors to regulate egg laying in response to seasonal temperature variations.

The bag cells of the opisthobranch mollusk Aplysia have become a thoroughly studied neuroendocrine model. The bag cell system allows unusual biophysical and biochemical accessibility for both in vitro and in vivo experimental analysis. The neurosecretory bag cells are anatomically isolated from other neurons and appear to be homogeneous in their biochemical and electrophysiological properties. For these reasons, and because they

\footnotetext{
Received July 19, 1990; revised Nov. 21, 1990; accepted Jan. 30, 1991.

We wish to thank Dr. E. Silinsky for his valuable suggestions and generous provision of facilities, Dr. J. E. Blankenship for supplying the Aplysia brasiliana. Dr. A. Telser for graphics, H. A. Jones for inspiration, and J. T. Baylen for technical assistance. This work was supported by NIH Grants RR-05370, GM-35115, and NS-27150.

Correspondence should be addressed to Robert Berry, Department of Cell, Molecular, and Structural Biology, Northwestern University Medical School, 303 East Chicago Avenue, Chicago, IL 60611 .

Copyright @ 1991 Society for Neuroscience $0270-6474 / 91 / 111780-06 \$ 03.00 / 0$
}

undergo prolonged changes in excitability that can be directly related to alterations in the behavior of the animal, thesc ncurons have proven to be an important model system for the investigation of the biochemical mechanisms that regulate neuronal excitability.

The bag cells, located on the abdominal ganglion in paired clusters, are responsible for the secretion of a peptide egg-laying hormone (ELH) that triggers egg laying (reviewed in Arch and Berry, 1989). During the egg-laying season, these cells secrete ELH during a discharge that lasts about 30 min (Kupfermann and Kandel, 1970) and occurs approximately once per day (Pinsker and Parsons, 1985). Electrophysiologically, a brief presynaptic input evokes a full-blown discharge during which synchronized activity spreads within a cluster and between clusters. The discharge terminates spontaneously and is followed by a refractory period of approximately $20 \mathrm{hr}$, during which the bag cells are inexcitable (Kupfermann and Kandel, 1970). The biophysical and biochemical mechanisms responsible for this stereotyped series of events have been the subjects of extensive investigation. The variations in membrane excitability that give rise to the bag cell discharge and the ensuing refractory period are under the control of intracellular messengers (reviewed in Kaczmarek et al., 1985; Arch and Berry, 1989). Specifically, elevations in bag cell cAMP are correlated with, and lead to, increased bag cell excitability (Kaczmarek et al., 1978). In addition to ELH, at least four other peptides derived from the ELH precursor (proELH; Scheller et al., 1983) are secreted during bag cell discharges (Sigvardt et al., 1986), and some of these are capable of modifying the electrophysiological behavior of the bag cells themselves (Rothman et al., 1983; Rock et al., 1986; Kauer et al., 1987; Brown and Mayeri, 1989). Of these, $\alpha$-bag cell peptide ( $\alpha$-BCP) has been studied the most extensively. $\alpha$-BCP has been reported to evoke the bag cell discharge, thereby suggesting that the potential feedback effects of this peptide are autoexcitatory (Rothman et al., 1983; Rock et al., 1986; Brown and Mayeri, 1989). However, these findings have been contradicted by reports that $\alpha$-BCP terminates the bag cell discharge and inhibits the increase in bag cell cAMP levels that occurs during the bag cell discharge or in response to the adenylate cyclase activator forskolin (Kauer et al., 1987; Berry, 1988). Other work, utilizing a membrane preparation, demonstrated more proximal effects of $\alpha$-BCP, namely, an inhibition of stimulated bag cell adenylate cyclase activity (Redman and Berry, 1990). These results lead to the conclusion that $\alpha$-BCP functions in an autoinhibitory manner. Kauer et al. (1987) suggested that the abdominal ganglia may be more excitable in response to $\alpha$-BCP in animals anesthetized with $\mathrm{MgCl}_{2}$. However, Brown and Mayeri (1989) found no difference in response to $\alpha$-BCP when comparing animals anesthetized with $\mathrm{MgCl}_{2}$ to 
those that were not. In reviewing this literature, it becomes apparent that all of the reported excitatory effects of $\alpha$-BCP were obtained at room temperature $\left(20-22^{\circ} \mathrm{C}\right)$, whereas effects consistent with bag cell inhibition were seen in experiments conducted at $14-15^{\circ} \mathrm{C}$. These temperatures are, respectively, within the summer and winter environmental ranges experienced by A. californica (Kupfermann and Carew, 1974; Audesirk, 1979).

Egg laying in Aplysia, as in many other spccics, is not constant throughout the year, but varies seasonally (Audesirk, 1979; Pinsker and Parsons, 1985). A. californica typically lays eggs only in the summer and early fall. While maturation and an adequate food supply (Carefoot, 1967; Smith and Carefoot, 1967; Gev et al., 1984) play enabling roles in the induction of egg laying, both laboratory and field studies indicate that increasing water temperature initiates or facilitates the behavior (Carefoot, 1967; Smith and Carefoot, 1967; Berry, 1984; Gev.et al., 1984; Pinsker and Parsons, 1985). In vivo studies have revealed that bag cell discharges invariably precede egg laying (Pinsker and Dudek, 1977), implying that the point(s) of temperature control must be at or upstream from the bag cells. Moreover, it has been shown that a shift from $15^{\circ} \mathrm{C}$ to $20^{\circ} \mathrm{C}$ in the holding conditions mimics the twofold elevation of proELH synthesis that develops in summer animals (Berry, 1984). In view of the contradictory reports concerning the functional role of $\alpha$-BCP, it is plausible to hypothesize that the electrophysiological effects of $\alpha-\mathrm{BCP}$ are temperature dependent, and that the peptide could play a role in determining the seasonality of egg laying by influencing bag cell excitability in a temperature-dependent manner. We report here electrophysiological and biochemical tests of this hypothesis.

\section{Materials and Methods}

Animals. Aplysia californica weighing $200-400 \mathrm{gm}$ were oblained from Marinus (Long Beach, CA) and held at $15^{\circ} \mathrm{C}$ in Instant Ocean (Aquarium Systems, Mentor, $\mathrm{OH}$ ) from 2 to $21 \mathrm{~d}$ before use. Aplysia brasiliana were supplied by Dr. J. E. Blankenship (Marine Biomedical Institute, Galveston, TX) and maintained at $20^{\circ} \mathrm{C}$ from 2 to $10 \mathrm{~d}$ before use. Animals were relaxed for dissection without the injection of $\mathrm{MgCl}_{2}$ by gently supporting them in the aquarium until they relaxed spontaneously. The experiments reported here were performed between August 1989 and July 1990 . However, each set of experiments at different temperatures was performed on the same day or within a day of each other.

Reagents. $\alpha-\mathrm{BCP}(1-7)$ was supplied by Peninsula Laboratories (Belmont, CA) and used at $1.0 \mu \mathrm{g} / \mathrm{ml}$. It has been shown previously that the influence of $\alpha-\mathrm{BCP}(1-8)$ and (1-9) on bag cell cAMP levels is qualitatively similar to that of the heptapeptide (Berry, 1988). The forskolin analog $7 \beta$-deacetyl-7 $\beta$ - $(\gamma-N$-methylpiperazino)-butyryl-forskolin (L858051) was obtained from Calbiochem (San Diego, CA), kept as a 10 mu stock solution in distilled water at $4^{\circ} \mathrm{C}$, and used at a final concentration of $10 \mu \mathrm{M}$. EGTA, 3-isobutyl-1-methylxanthine (IBMX), bacitracin, and soybean and egg-white trypsin inhibitors were all obtained from Sigma (St. Louis, MO).

Electrophysiology. Intracellular recordings were made using conventional techniques. The recording chamber $(3 \mathrm{ml})$ was contained within an outer chamber $(150 \mathrm{ml})$ in which water was circulated from a refrigerated water bath (Haake Instruments). The temperature was monitored with a thermistor (Yellow Springs Instruments) in the recording chamber and was found to vary around the set temperature by no more than $\pm 0.15^{\circ} \mathrm{C}$. Bag cells in intact abdominal ganglia were impaled through the intact sheath with glass micruelectrodes filled with $3 \mathrm{M} \mathrm{KCl}$ with resistances of 15-30 M . Abdominal ganglia were held in the recording chamber in artificial seawater at the appropriate temperature (either $15^{\circ} \mathrm{C}$ or $20^{\circ} \mathrm{C}$ ) for a minimum of 30 min before impalement. (The $\mathrm{pH}$ of the artificial seawater was constant over this range of temperature.) After the resting potential had stabilized for at least $10 \mathrm{~min}$, the bath solution was changed. Seventy percent of the bath solution was removed with a syringe and replaced with the appropriate solution. This proce-
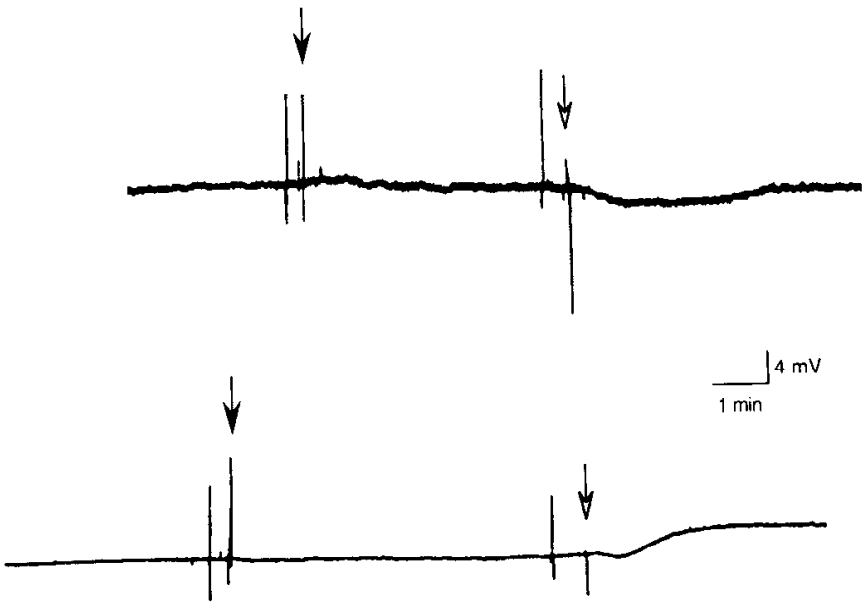

Figure 1. Temperature-dependent effect of $\alpha$-BCP on bag cell membrane potential. Intracellular recordings from separate bag cells exposed to $1.0 \mu \mathrm{g} / \mathrm{ml} \alpha-\mathrm{BCP}$ are shown at $15^{\circ} \mathrm{C}$ (top trace) and $20^{\circ} \mathrm{C}$ (bottom trace). In each case, the bathing medium was initially artificial seawater, then was changed to a solution of protease inhibitors (solid arrows; 250 $\mu \mathrm{g} / \mathrm{ml}$ ), then replaced with a solution of $\alpha-\mathrm{BCP}$ in protease inhibitors (open arrows). The addition of protease inhibitors alone did not alter the membrane potential significantly at either temperature.

dure allowed the preparation to be immersed at all times, and yet replacing the majority of the bath solution minimized the diffusion time of the peptide. All solutions were held within the water bath prior to use, and the temperature offset between the water bath and the recording chamber was less than $1^{\circ} \mathrm{C}$. Because the $\alpha$-BCP was in a solution of protease inhibitors $(250 \mu \mathrm{g} / \mathrm{ml}$ each of soybean and egg-white trypsin inhibitor and bacitracin), we first replaced the chamber solution with protease inhibitors and noted any change in membrane potential. Any such changes were always small $(<1 \mathrm{mV})$ and inconsistent in dircetion. $\alpha$-BCP was then added to the chamber, and again, any alteration in membrane potential was recorded.

Extracellular recordings were made using bag cell organs isolated from the abdominal ganglion. One organ was exposed to $\alpha$-BCP, while the other acted as a control. Organs were incubated for $30 \mathrm{~min}$ at $15^{\circ} \mathrm{C}$ or $20^{\circ} \mathrm{C}$, then either protease inhibitors or a solution of $\alpha-\mathrm{BCP}$ and protease inhibitors was added to the chamber as described above. Clusters were continuously monitored while incubating for an additional $20 \mathrm{~min}$ before being stimulated via a suction electrode on the pleuroabdominal connective nerve. The discharge was measured with a suction electrode surrounding the bag cell cluster. At the end of the discharge, the organ was stimulated again to verify that the bag cells had entered the refractory state that characterizes discharge termination.

Cyclic nucleotide assays. The assay used to determine cAMP levels in bag cell organs was similar to that already described (Berry, 1988). Briefly, isolated bag cell organs were incubated within a circulating refrigerated water bath for $30 \mathrm{~min}$ at the desired temperature with or without $1 \mu \mathrm{g} / \mathrm{ml} \alpha$-BCP (one cluster from each animal acted as a control). The variation around the set temperature was $\pm 0.15^{\circ} \mathrm{C}$ and was measured by a thermistor. In some cases, both control and experimental organs were exposed to L-858051. The incubation was followed by a 2 -min rinse in $1 \mathrm{mM}$ IBMX. Organs were then homogenized in acidified ethanol, and cAMP levels were determined by radioimmune assay (Biomedical Technologies, Staughton, MA).

The activity of adenylate cyclase was determined by measuring the amount of cAMP formed in a preparation of homogenized bag cells. This assay is based upon the protocol of Eskin and Takahashi (1983), and the modifications have been described elsewhere (Redman and Berry, 1990).

\section{Results}

Electrophysiology. We obtained intracellular recordings from bag cells to determine the effect of $\alpha$-BCP on membrane potential at both $15^{\circ} \mathrm{C}$ and $20^{\circ} \mathrm{C}$. As illustrated in Figure 1, $\alpha-\mathrm{BCP}$ 

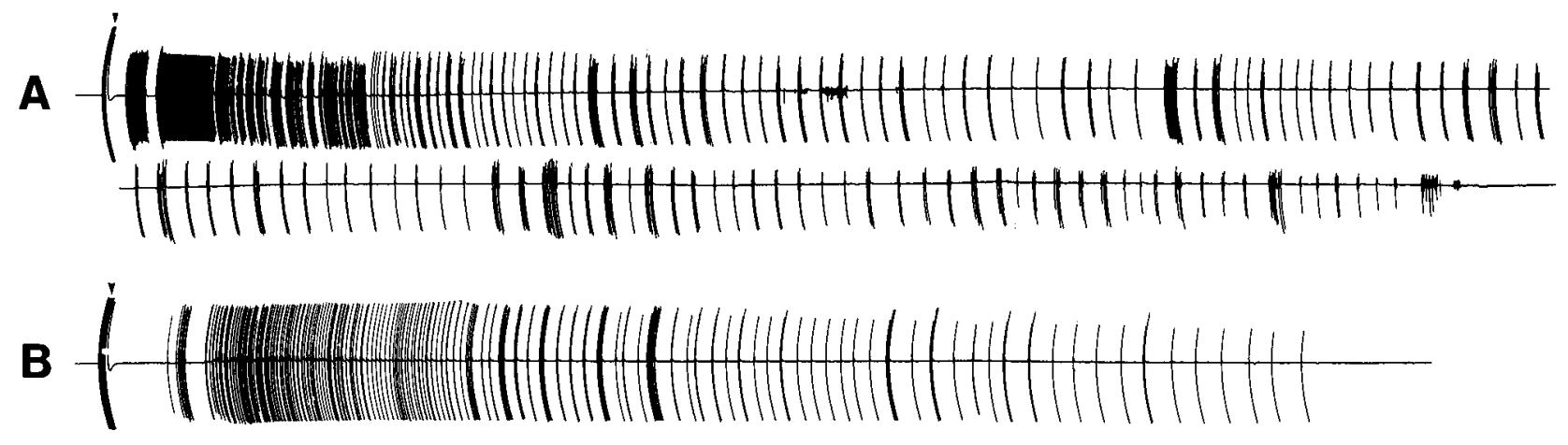

$1 \mathrm{~min}$
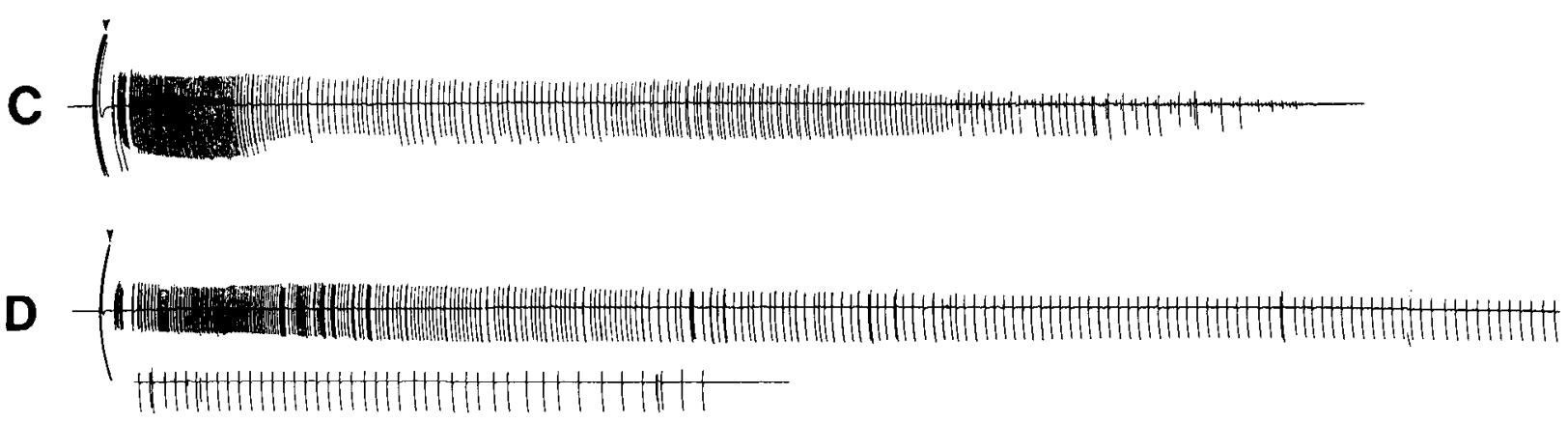

Figure 2. Temperature-dependent effect of $\alpha$-BCP on bag cell discharges. One cluster from each animal was incubated in a solution of $1 \mu \mathrm{g} / \mathrm{ml}$ $\alpha$-BCP and $250 \mu \mathrm{g} / \mathrm{ml}$ protease inhibitors, while the other acted as control and was incubated in protease inhibitors alone. Traces $A$ and $B$ show discharges elicited by stimulation (arrowhead) of the connective nerve at $15^{\circ} \mathrm{C}$, while traces $C$ and $D$ are from clusters at $20^{\circ} \mathrm{C}$. The organs in traces $B$ and $D$ were superfused with $1 \mu \mathrm{g} / \mathrm{ml} \alpha$-BCP for 30 min preceding stimulation. All organs proved to be refractory upon further stimulation. Unlabeled traces below $A$ and $D$ are continuations of the labeled traces.

hyperpolarized bag cells at $15^{\circ} \mathrm{C}$, but depolarized them at $20^{\circ} \mathrm{C}$. At $15^{\circ} \mathrm{C}$, hyperpolarizations ranging from 1 to $14 \mathrm{mV}(-4.3 \pm$ $1.3 \mathrm{mV}$, mean $\pm \mathrm{SEM}$ ) were observed in 11 out of 13 preparations (no significant change was noted in the other two preparations), whercas dcpolarizations ranging from 2 to $5 \mathrm{mV}(+3.7$ $\pm 0.5 \mathrm{mV}$ ) were obtained in six out of six preparations at $20^{\circ} \mathrm{C}$. The median length of the hyperpolarization was $3.5 \mathrm{~min}$, while the median for depolarizations was $4.0 \mathrm{~min}$. The initial resting potential was approximately the same at both $15^{\circ} \mathrm{C}(-49.1 \pm$ $3.5 \mathrm{mV})$ and $20^{\circ} \mathrm{C}(-50.8 \pm 3.8 \mathrm{mV})$. In three of the six experiments at $20^{\circ} \mathrm{C}$, the depolarization was preceded by a smaller hyperpolarization, as in the example in Figure 1. Both responses to $\alpha$ - $\mathrm{BCP}$, the hyperpolarization at $15^{\circ} \mathrm{C}$ and the depolarization at $20^{\circ} \mathrm{C}$, became desensitized after the initial response. Our results at $15^{\circ} \mathrm{C}$ confirm the previously reported autoinhibitory effects of $\alpha-\mathrm{BCP}$ at $14^{\circ} \mathrm{C}$ (Kauer et al., 1987), and our results at $20^{\circ} \mathrm{C}$ are in accord with the previous findings of excitatory effects of $\alpha$-BCP at room temperature (Rothman et al., 1983; Rock et al., 1986; Brown and Mayeri, 1989).

Extracellular recordings were used to determine if $\alpha$-BCP affects the characteristics of the discharge in a manner consistent with its temperature-dependent effects on membrane potential. In our hands, $\alpha$-BCP never prevented a discharge from being elicited by extracellular stimulation at $15^{\circ} \mathrm{C}(n=11)$, nor did it ever initiate a discharge at $20^{\circ} \mathrm{C}(n=12)$. However, it did alter the duration of the stimulated discharge and the number of compound action potentials produced during the discharge (Fig. 2). At $15^{\circ} \mathrm{C}, \alpha$-BCP shortened the discharge by $43 \pm 6.4 \%$ (percent of control \pm SEM) and decreased the total number of action potentials generated by $34 \pm 6.7 \%$. At $20^{\circ} \mathrm{C}, \alpha$-BCP lengthened the discharge by $94 \pm 17 \%$ and increased the total number of action potentials per discharge by $41 \pm 8 \%$. These results demonstrate a temperature-dependent modulatory effect of the peptide on discharge characteristics.

\section{Alteration of cAMP levels}

To test the hypothesis that the temperature dependence of $\alpha$-BCP's electrophysiological actions might reflect a temperature dependence of its influence on cAMP, we measured the peptide's effect on bag cell cAMP levels at various temperatures throughout the animal's natural environmental range. In this set of experiments, both Aplysia californica and Aplysia brasiliana were tested. As shown in Figure 3, the effect of the pcptide on cAMP levels in intact bag cells was highly temperature dependent, switching from inhibition to enhancement over a $2.5^{\circ} \mathrm{C}$ range. At and below $15^{\circ} \mathrm{C}$, the peptide caused a depression in cAMP levels, whereas at $17.5^{\circ} \mathrm{C}$ and above, an elevation was produced. In the absence of the peptide, cAMP levels were constant throughout the temperature range of $12.5-20^{\circ} \mathrm{C}$, but decreased by $24 \%$ at $22.5^{\circ} \mathrm{C}$. The reduction in the peptide's effect parallels this decrease. The curves generated for the two species are quite similar even though $A$. brasiliana were maintained at a higher temperature before use.

In addition, using only $A$. californica, we observed a similar effect on bag cell cAMP levels in the presence of L-858051, an adenylate cyclase-stimulating derivative of forskolin: at $15^{\circ} \mathrm{C}$, $\alpha$-BCP reduced the stimulated levels of cAMP by $25.3 \pm 3 \%$ (percent of control $\pm \mathrm{SEM} ; n=6$ ), whereas at $20^{\circ} \mathrm{C}$ the peptide 
further enhanced the level of cAMP stimulation by $30 \pm 5 \%(n$ $=6$ ). This series of experiments indicates that $\alpha$-BCP alters bag cell cAMP levels in the same manner that it alters bag cell electrophysiology.

\section{Adenylate cyclase activity}

The above results suggest that the peptide's shift in function could be the result of the change in cAMP lcvels. cAMP lcvels reflect the relative activities of adenylate cyclase and cyclic nucleotide phosphodiesterase. We have already shown that $\alpha$-BCP decreases stimulated adenylate cyclase activity via an inhibitory GTP-binding protein $\left(\mathrm{G}_{i}\right)$, using a membrane preparation (Redman and Berry, 1990). Because this preparation minimizes the influences of metabolic feedback and interactions with other transmitters, we used it to study the effect of temperature on adenylate cyclase activity. In the previous study, enzyme activity was measured at $30^{\circ} \mathrm{C}$. Although this temperature enhances enzymatic activity, it is not within the environmental range of the animal. Therefore, we repeated the assay at $15^{\circ} \mathrm{C}$. This modification did not alter the results. $\alpha$-BCP did not modify basal levels of adenylate cyclase activity at either temperature, but inhibited L-858051-stimulated activity by approximately $24 \pm$ $5 \%$ (percent of control $\pm \mathrm{SEM} ; n=6$ ) at $15^{\circ} \mathrm{C}$, compared to the $26 \pm 3 \%(n=10)$ inhibition previously obtained at $30^{\circ} \mathrm{C}$. Thesc results indicate that the mechanism responsible for the reversal of the peptide's function with temperature is either unavailable or is no longer functional in this membrane preparation.

\section{Effect of low-Ca ${ }^{2+} /$ high- $\mathrm{Mg}^{2+}$ solution}

The foregoing result raises the possibility that the excitatory effect of the peptide at higher temperatures depends on its activation of the secretion of an excitatory factor, either from a presynaptic structure or from the bag cells themselves. Such a mechanism should be functional in the intact organ, but inoperative in the homogenized bag cell preparation. Furthermore, it should be possible to block such a mechanism by incubation in low-Ca ${ }^{2+} /$ high- $\mathrm{Mg}^{2+}$ medium, because this treatment has been shown to block secretion in this system (Arch, 1972). To test this hypothesis, we determined the effect of $\alpha$-BCP on bag cell cAMP levels in artificial seawater containing $1 \mathrm{mM} \mathrm{Ca}^{2+}$ and $100 \mathrm{mM} \mathrm{Mg}^{2+}$. When secretion was blocked by this treatment, $\alpha$-BCP reduced cAMP levels by $11 \pm 2.5 \%(n=5)$ at $20^{\circ} \mathrm{C}$ as well as by $15 \pm 3 \%(n=6)$ at $15^{\circ} \mathrm{C}$. This result suggests that $\alpha$-BCP's effect at the higher temperature may be mediated by a secretory process.

\section{Discussion}

These results demonstrate that the feedback effect of $\alpha-\mathrm{BCP}$ on Aplysia bag cells is highly temperature dependent, and in such a way as to suggest a role for the peptide in determining the seasonality of egg laying in this animal. Intracellular recordings confirmed previous reports that $\alpha$-BCP causes a small hyperpolarization of bag cells at $15^{\circ} \mathrm{C}$ (Kauer et al., 1987), and that this membrane effect reverses to a small depolarization at $20^{\circ} \mathrm{C}$ (Brown and Mayeri, 1989). Although termination of the discharge at the lower temperature (Kauer et al., 1987) and initiation of discharges at the higher temperature (Brown and Mayeri, 1989) are among the reported effects of the peptide, and would be qualitatively consistent with our intracellular results, initiation and termination of bag cell discharges were not apparent under the conditions of our experiments. We did, however, observe that the peptide shortened bursts at the lower

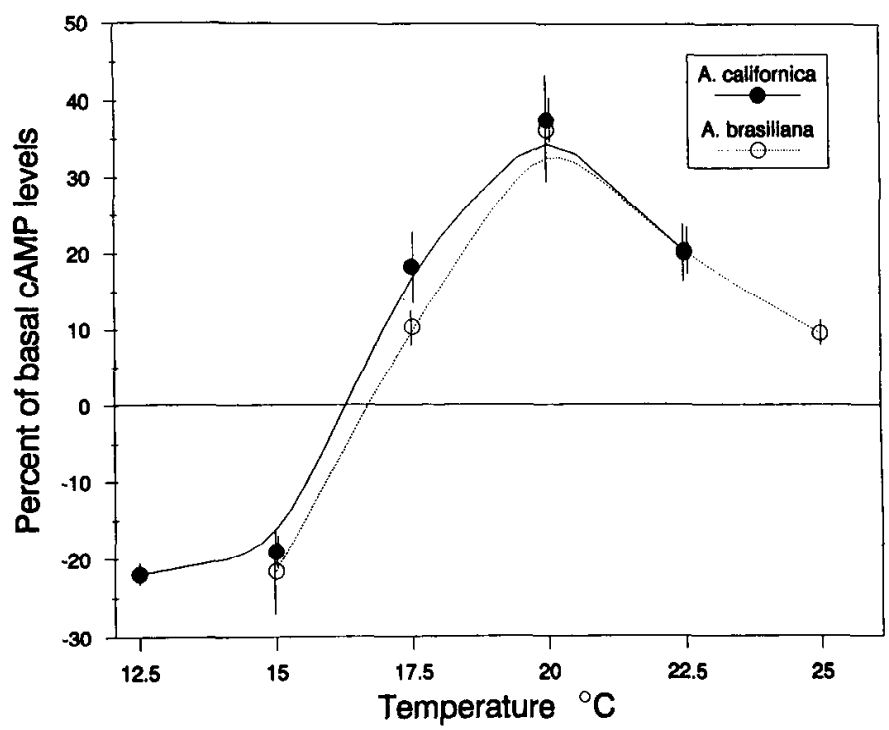

Figure 3. Temperature-dependent effect of $\alpha$-BCP on bag cell cAMP levels in Aplysia californica (solid circles) and Aplysia brasiliana (open circles). The vertical axis represents the percent difference between organs exposed to $1.0 \mu \mathrm{g} / \mathrm{ml} \alpha-\mathrm{BCP}$ and controls. For all temperatures, $n$ $=5$, except $22.5^{\circ} \mathrm{C}$, for which $n=3$.

temperature and extended them at the higher one. The more modulatory effects seen in our experiments may reflect variations in the effective concentration of the applied peptide, mode of application, time of year, parameters of electrical stimulation, or other factors, but they provide qualitative support for the cited studies. Moreover, it is unlikely that any of the methods used to apply the peptide in this or the studies cited above adequately mimic the physiological situation, which would consist of the pulsatile release of an unknown quantity of $\alpha$-BCP at steadily increasing intervals throughout the discharge (e.g., Fig. 2). It is also important to note that $\alpha$-BCP does not mimic the influence of temperature on discharge duration: control discharges are actually $40 \%$ longer at $15^{\circ} \mathrm{C}$ than at $20^{\circ} \mathrm{C}$. This suggests that other temperature-dependent factors have a grcater role in controlling discharge duration than does $\alpha-\mathrm{BCP}$. This consideration does not, however, negate the conclusion that the peptide's effect on bag cell excitability is consistent with its effect on membrane potential.

$\alpha$-BCP decreased cAMP levels in intact bag cells at $15^{\circ} \mathrm{C}$, but increased them at $20^{\circ} \mathrm{C}$. This result is true for $A$. californica as well as for $A$. brasiliana. We included the latter species in this experiment because it can experience a similarly wide variation in ocean temperature $\left(14-25^{\circ} \mathrm{C}\right)$ as $A$. californica $\left(12-25^{\circ} \mathrm{C}\right.$; Kupfermann and Carew, 1974), but with a higher average temperature (Pinsker and Parsons, 1985). Although $A$. brasiliana are mich less seasonal in their egg-laying activity (Pinsker and Parsons, 1985) and are considered a "warm-water" animal, our results indicate that their mechanism of response to $\alpha$-BCP exhibits the same temperature dependence as the "cold-water" $A$. californica, perhaps to allow them to survive during the somctimes drastic fluctuations in ocean temperature during seasonal changes.

The result of this experiment has another consequence, as well. The $A$. brasiliana were held at $20^{\circ} \mathrm{C}$ before experimentation to approximate their previous holding conditions (J. E. Blankenship, personal communication). This seemed not to alter the 
results of the experiment. In other words, the temperature dependence of $\alpha$-BCP's influence on bag cell cAMP levels appears to be a function of the ambient temperature experienced by the bag cells within, at most, the last $0.5 \mathrm{hr}$, rather than the temperature at which the animal had been held for days to weeks. Furthermore, it is important to note that the $A$. brasiliana bag cells were being cooled in vitro in experiments at $17.5^{\circ} \mathrm{C}$ and lower, whereas the $A$. californica bag cells were being warmed at $17.5^{\circ} \mathrm{C}$ and higher, yet their responses were virtually identical. This result argues that the reversal of $\alpha$-BCP's influence on cAMP in the transition zone $\left(15-20^{\circ} \mathrm{C}\right)$ is not a result of accelerated degeneration of the preparation at the higher temperatures within this range.

Our finding that $\alpha$-BCP's influence on bag cell cAMP levels parallels its effects on membrane potential and discharge duration is in accord with the well-developed notion that bag cell excitability is positively correlated with bag cell cAMP levels (Kaczmarek et al., 1978, 1985). However, this does not mean that the peptide's effects on ELH secretion are entirely due to its effects on bag cell electrophysiology. In the bag cells, cAMP enhances proELH synthesis (Bruehl and Berry, 1985), may enhance proELH processing (Azhderian and Kaczmarek, 1986), and allows presumptive secretory granules to enter the growth cones of cultured bag cells (Forscher et al., 1987). Thus, there is some precedent for the suggestion that the peptide's effect on ELH secretion may transcend its effect on bag cell electrophysiology.

In any event, the temperature dependence of $\alpha$-BCP's influence on bag cell electrophysiology and cAMP levels implies that the point at which the peptide modulates bag cell discharges is at or upstream from the bag cells. Our further results, however, do not implicate bag cell adenylate cyclase as the point of temperature-dependent control: the peptide was invariably inhibitory in in vitro enzyme assays. Moreover, we have previously presented substantial evidence that the inhibition of bag cell membrane adenylate cyclase at $30^{\circ} \mathrm{C}$ is mediated by a inhibitory GTP-binding protein (Redman and Berry, 1990). The present results imply that this mechanism also operates at $15^{\circ} \mathrm{C}$. Thus, the temperature dependence of the peptide's effect must lie upstream from its receptor-mediated action on bag cell adenylate cyclase.

The blockage of $\alpha$-BCP's elevation of bag cell cAMP levels at $20^{\circ} \mathrm{C}$ by a low- $\mathrm{Ca}^{2+} /$ high- $\mathrm{Mg}^{2+}$ medium suggests that the temperature-dependent process is mediated by, or at least sensitive to, $\mathrm{Ca}^{2+}$. There is no lack of $\mathrm{Ca}^{2+}$-dependent regulatory mechanisms that might account for this result. However, it is known that bag cell cAMP levels are not altered in $\mathrm{Ca}^{2+}$-deficient medium (Bruehl and Berry, 1985), and that the effect of the peptide on bag cell adenylate cyclase is not temperature sensitive (Redman and Berry, 1990). This would argue that the $\mathrm{Ca}^{2+}$-sensitive effect of the peptide at $20^{\circ} \mathrm{C}$ is upstream from the bag cells. The most plausible mechanism to account for these results would be that the temperature-dependent process involves $\alpha$-BCP's induction of the sccretion of a substance that causes the elevation of cAMP levels in bag cells. This conclusion is quite apart from the question of the extent to which the peptide's electrophysiological effects are due to its influence on the bag cell cAMP system. This question, as well as the site at which $\mathrm{Ca}^{2+}$ exerts its influence, deserves further study.

Nonetheless, both past and present results can be reconciled into a single unifying hypothesis: the direct effect of $\alpha$-BCP on membranes would be, at all temperatures, a $G_{i}$-mediated in- hibition of adenylate cyclase, resulting in a decrease in bag cell cAMP levels, a hyperpolarization, and reduced excitability. At higher temperatures, an indirect effect of $\alpha$-BCP would also take effect, whereby the peptide evokes the release of an excitatory factor that overrides the direct effect of the peptide. Such release could be from bag cells, modulatory terminals, or excitatory terminals projecting from higher structures. Such a dual mechanism could explain the hyperpolarization that precedes the depolarization evoked by $\alpha$-BCP at $20^{\circ} \mathrm{C}$ (Fig. 1). It could also explain why the peptide lowers basal cAMP levels, but only reduces stimulated, not basal, adenylate cyclase activity. This further explanation assumes that, under unstimulated conditions, the intact bag cells receive a low level of tonic stimulatory input, which provides a small level of stimulated adenylate cyclase activity.

Based on experiments performed at room temperature, it has been suggested that feedback from $\alpha$-BCP may play a role in the initiation and spread of a discharge (Brown and Mayeri, 1989). Conversely, experiments at $14-15^{\circ} \mathrm{C}$ suggested a role in discharge termination (Kauer et al., 1987; Berry, 1988; Redman and Berry, 1990). Regardless of the mechanism, the results reported here suggest that $\alpha$-BCP plays both functional roles and that the specific role is determined by temperature. Under this hypothesis, at either temperature, any combination of pre- or postsynaptic events that might activate the most excitable members of the bag cell population would result in the secretion of $\alpha$-BCP onto those and other members of the cluster. The characteristics of $\alpha$-BCP's actions are such that, at typical winter temperatures, this would reduce excitability in the bag cell population, possibly aborting an inopportune discharge. At summer temperatures, however, the excitatory properties of the peptide could help to initiate, spread, and prolong the discharge. Thus, this peptide elicits the electrophysiological and biochemical responses that would be expected of a temperature-dependent "switch" mediating the transition of egg laying that occurs as environmental temperature increases during the summer.

\section{References}

Arch S (1972) Polypeptide secretion from the isolated parietovisceral ganglion of Aplysia californica. J Gen Physiol 59:47-59.

Arch S, Berry RW (1989) Molecular and cellular regulation of neuropeptide expression: the bag cell model system. Brain Res Rev 14: 181-201.

Audesirk T (1979) A field study of growth and reproduction in Aplysia californica. Biol Bull 157:407-421.

Azhderian E, Kaczmarek LK (1986) Onset of discharge and elevations of cyclic AMP stimulate prohormone processing in bag cell neurons. J Cell Biol 103:709.

Berry KW (1984) Environmental temperature modulates the rate of synthesis of egg-laying hormone in Aplysia. J Comp Physiol B 154: 545-548.

Berry RW (1988) Alpha bag cell peptide reduces stimulated cAMP levels and proELH synthesis in bag cells. Mol Brain Res 4:267-271.

Brown RO, Mayeri F (1989) Positive feedback by autoexcitatory neuropeptides in neuroendocrine bag cells of Aplysia. J Neurosci 9:14431451 .

Bruehl CL, Berry RW (1985) Regulation of synthesis of the neurosecretory egg-laying hormone of Aplysia: antagonistic roles of calcium and cyclic adenosine $3^{\prime}: 5^{\prime}$-monophosphate. J Neurosci 5:1233-1238.

Carefoot TH (1967) Studies on a sublittoral population of Aplysia punctata. J Mar Assoc UK 47:335-350.

Eskin A, Takahashi JS (1983) Adenylate cyclase activation shifts the phase of a circadian pacemaker. Science 220:82-84.

Forscher P, Kaczmarek LK, Buchanan J, Smith SJ (1987) Cyclic AMP induces changes in distribution and transport of organelles within growth cones of Aplysia bag cell neurons. J Neurosci 7:3600-3611.

Gev S, Achituv Y, Susswein AJ (1984) Seasonal determinants of the 
life cycle in two species of Aplysia found in shallow waters along the Mediterranean coast of Israel. J Exp Mar Biol Ecol 74:67-83.

Kaczmarek LK, Jennings K, Strumwasser F (1978) Neurotransmitter modulation, phosphodiesterase inhibitor effects, and cyclic AMP correlates of afterdischarge in peptidergic neurites. Proc Natl Acad Sci USA 75:5200-5204.

Kaczmarek LK, Strong JA, Kauer JA (1985) The role of protein kinases in the control of prolonged changes in neuronal excitability. Prog Brain Res 69:77-90.

Kauer JA, Fisher TE, Kaczmarek LK (1987) Alpha bag cell peptide directly modulates the excitability of the neurons that release it. $J$ Neurosci 7:3623-3632.

Kupfermann I, Carew TJ (1974) Behavior patterns of Aplysia californica in its natural environment. Behav Biol 12:317-337.

Kupfermann I, Kandel ER (1970) Electrophysiological properties and functional interconnections of two symmetrical neurosccrctory clusters (bag cells) in abdominal ganglion of Aplysia. J Neurophysiol 33: 865-876.

Pinsker HM, Dudek FE (1977) Bag cell control of egg laying in freely behaving Aplysia. Science 197:490-493.

Pinsker HM, Parsons DW (1985) Temperature dependence of egg- laying in Aplysia brasiliana and Aplysia californica. J Comp Physiol B 156:21-27.

Redman RS, Berry RW (1990) $\alpha$-Bag cell peptide inhibits bag cell adenylate cyclase via a GTP-dependent mechanism. Mol Brain Res 8:99-103.

Rock MK, Shope SB, Blankenship JE, Schlesinger DH (1986) Effects of synthetic bag cell and atrial gland peptides on identified nerve cells in Aplysia. J Neurobiol 17:273-290.

Rothman BS, Mayeri E, Brown RO, Yuan P-M, Shively JE (1983) Primary structure and neuronal effects of alpha-bag cell peptide, a second candidate neurotransmitter encoded by a single gene in bag cell neurons of Aplysia. Proc Natl Acad Sci USA 80:5753-5754.

Scheller RH, Jackson JF, McAllister LB, Rothman BS, Mayeri E, Axel R (1983) A single gene encodes multiple neuropeptides mediating a stereotyped behavior. Cell 32:7-223.

Sigvardt KA, Rothman BS, Brown RO, Mayeri E (1986) The bag cells of Aplysia as a multitransmitter system: identification of alpha bag cell peptide as a second neurotransmitter. J Neurosci 6:803-813.

Smith ST, Carefoot TH (1967) Induced maturation of gonads in Aplysia punctata Cuvier. Nature 215:652-653. 